\title{
GROWTH, PROPERTIES AND SENSOR APPLICATIONS OF LOW TEMPERATURE GROWN ZnO NANORODS
}

\author{
T. Serevičius and S. Juršènas \\ Institute of Applied Research, Vilnius University, Sauletekio 9-III, LT-10222 Vilnius, Lithuania \\ E-mail: tomas.serevicius@ff.stud.vu.lt
}

Received 28 October 2011; accepted 1 December 2011

\begin{abstract}
$\mathrm{ZnO}$ nanorods with the average diameter of about $60-300 \mathrm{~nm}$ have been grown by the low temperature aqueous chemical growth technique. The impact of growth time and reactant concentration on the morphology on $\mathrm{ZnO}$ structures was tested by scanning electron microscopy and photoluminescence spectroscopy. High optical quality of obtained $\mathrm{ZnO}$ nanorod films was evidenced by dominating free exciton transitions. The reduction of surface to volume ratio by increasing the diameter of $\mathrm{ZnO}$ nanorods resulted in a linear increase of excitonic luminescence intensity with respect to the defect related emission. Excellent photoluminescence properties and high surface area of $\mathrm{ZnO}$ nanorods can be used for the detection of organic contaminants dissolved in water. The quenching of both excitonic and defect luminescence was observed upon exposure of $\mathrm{ZnO}$ nanorod films to various organic contaminants.
\end{abstract}

Keywords: $\mathrm{ZnO}$, nanorods, low temperature growth, fluorescence sensor

PACS: 78.55.Cr, 78.67.Lt, 61.46.Km

\section{Introduction}

Zinc oxide is an attractive wide-bandgap semiconductor showing large exciton binding energy and enabling simple fabrication of variously shaped nanostructures [1]. Nanostructured $\mathrm{ZnO}$ offers some additional features, like quantum confinement, large surface area and waveguide behaviour that can be applied for $\mathrm{ZnO}$ based LEDs, solar cells, sensors and photocatalytic applications [2].

The low-temperature aqueous chemical growth (ACG) technique is very promising since it allows one to obtain well-oriented $\mathrm{ZnO}$ nanorods (NRs), it is of low cost and can be easily integrated with large-area low-cost organic semiconductor device technologies. In this letter we report on the growth and optical properties research of $\mathrm{ZnO} \mathrm{NR}$ films by the low temperature ACG technique. The sensing ability of the $\mathrm{ZnO}$ NR films of organic contaminants in water is tested.

\section{Experimental procedure}

Two sets of $\mathrm{ZnO}$ NRs on pre-treated glass substrates were prepared by the low temperature ACG technique. The details of the method and substrate pre-treatment can be found in [3]. In the first set, reactant concentration was varied from $0.05 \mathrm{M}$ to $0.175 \mathrm{M}$ while growth time was kept constant $(5 \mathrm{~h})$. Reactant concentration was constant $(0.1 \mathrm{M})$ and growth time was being increased from 3 to $7 \mathrm{~h}$ for the second set of samples. Growth temperature was $95^{\circ} \mathrm{C}$ in both cases.

The structure of $\mathrm{ZnO}$ NRs was analysed utilising the Oxford Apollo 300 scanning electron microscope (SEM). Luminescence properties were studied for low and high intensity excitation conditions. Low intensity excitation conditions were fulfilled by using a low power $(\sim \mu \mathrm{W})$ light emitting diode as an excitation source. Luminescence spectra were detected by CCD camera. High intensity excitation spectra were measured by using picosecond laser ( $\tau=25 \mathrm{ps}, h v=4.66 \mathrm{eV}$, excitation energy density $5 \mathrm{~mJ} / \mathrm{cm}^{2}$ ) and photomultiplier detection. The sensing properties of $\mathrm{ZnO}$ NRs were tested by comparing luminescence spectra of $\mathrm{ZnO}$ in distilled water and in $1 \%$ solution of methanol, dimethylsulfoxide and chloroform. In this case, $\lambda=310 \mathrm{~nm}$ wavelength dispersed by monochromator from a xenon lamp was used as an excitation source. 


\section{Experimental results and discussion}

Figure 1 shows SEM images of two sets of $\mathrm{ZnO}$ NRs grown with different duration (Fig. $1(\mathrm{a}, \mathrm{b})$ ) and with different reactant concentration (Fig. 1 (c, d)).

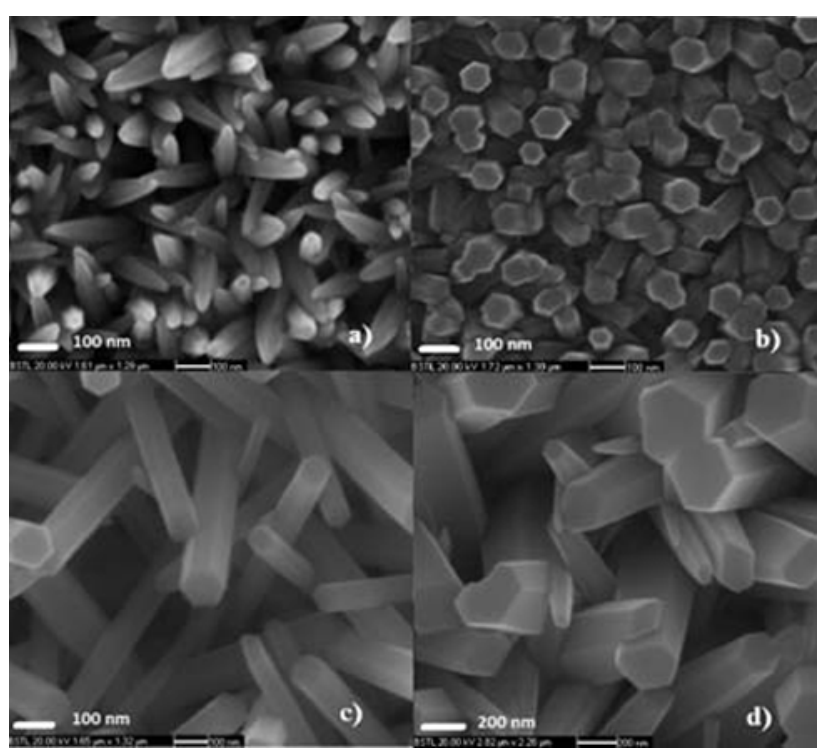

Fig. 1. Scanning electron microscope images of $\mathrm{ZnO}$ NRs grown in different conditions: (a) $t=3 \mathrm{~h}, n=0.1 \mathrm{M}$; (b) $t=7 \mathrm{~h}, n=0.1 \mathrm{M}$; (c) $t=5 \mathrm{~h}, n=0.05 \mathrm{M}$; (d) $t=5 \mathrm{~h}$, $n=0.175 \mathrm{M}$, where $t$ is growth time, $n$ is equimolar concentration of reagents. Growth temperature is $95^{\circ} \mathrm{C}$.

SEM pictures of prepared films show a nearly uniform layer of hexagonal $\mathrm{ZnO}$ nanorods (Fig. 1). The average diameter of NRs increases from 60 to $110 \mathrm{~nm}$, when the growth time is increased from 3 to $7 \mathrm{~h}$. The average diameter of $\mathrm{ZnO}$ NRs also increases from 60 to $300 \mathrm{~nm}$ with the increase of reactant concentration from 0.05 to $0.175 \mathrm{M}$. The length of NRs is about $2.5 \mu \mathrm{m}$. Since the density of NRs is almost uniform, thin nanorods are not perfectly aligned. The alignment increases for thick NRs due to higher density, which limits the possibility to grow in unparallel directions. However, a variation of NR alignment is still present in the same sample, though this variation is remarkably lower for NRs of a larger thickness. The density of $\mathrm{ZnO}$ NRs can be controlled by growth time alteration, while the diameter is more sensitive to variation in reactant concentration. The coalescence of neighbouring NRs was observed for the films with the average diameter of NRs exceeding the average value of $160 \mathrm{~nm}$. This effect was observed in both sets of samples.

The emission spectrum of $\mathrm{ZnO}$ NRs obtained at low intensity excitation is shown in Fig. 2. Two luminescence bands typical of high purity $\mathrm{ZnO}$ are observed: free exciton recombination band at $3.195 \mathrm{eV}$ and defect band at $2.35 \mathrm{eV}$. The origin of "green" defect band can be related to zinc vacancy states [4]. The spectral structure of luminescence spectra of all studied samples is almost the same. The only difference is the intensity ratio of excitonic and defect PL bands in samples of different NR diameter (see inset in Fig. 2). Free exciton luminescence intensity increases more rapidly than defect luminescence in accordance with the reduction of surface recombination. Excellent optical quality of the obtained $\mathrm{ZnO}$ NRs films is confirmed by similar results of the exciton and defect luminescence intensities observed in $\mathrm{ZnO}$ films deposited by molecular beam epitaxy [5].

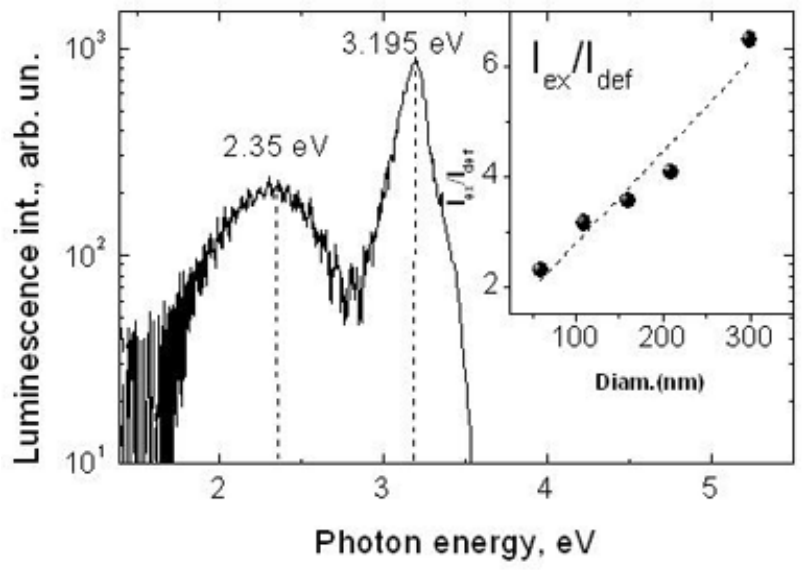

Fig. 2. Luminescence spectrum of $\mathrm{ZnO} N R s\left(t_{\text {growth }}=5 \mathrm{~h}\right.$, $\left.n_{\text {reactants }}=0.125 \mathrm{M}, T_{\text {growth }}=95^{\circ} \mathrm{C}\right)$. Inset depicts luminescence intensity ratio (exciton to defect) dependence on average NR diameter.

The latter trend was observed for the set of samples grown by varying the reactant concentration. The opposite trend was observed for the set of samples grown at various growth time. A decrease of exciton luminescence in comparison with defect emission was observed when the average diameter of NRs was increased and can be tentatively attributed to the emergence of non-radiative defect states under variation of growth time. 
Shallow and deep defect states are saturated at high excitation conditions, thus information about dominating near band-edge recombination mechanisms can be obtained. Luminescence spectrum at high excitation conditions shows a sole exciton luminescence band at $3.19 \mathrm{eV}$. The luminescence intensity dependence on excitation density is linear, which is typical of free exciton recombination. Free exciton luminescence intensity increases linearly together with increasing NR diameter up to $160 \mathrm{~nm}$. Further increase of $\mathrm{ZnO} \mathrm{NR}$ diameter leads to a decrease of PL intensity. It can be attributed to the emergence of non-radiative structural defect states, which occurs due to coalescence of NRs. This effect was observed in both sets of the samples.

The luminescence intensity of $\mathrm{ZnO}$ NR films embedded in a clean ambient is governed by intrinsic recombination processes. When $\mathrm{ZnO}$ NRs are in a polluted ambient, e. g. in water with organic contaminants, these molecules adsorb on NR surface and start to capture photoexcited holes [6]. This causes a pronounced emission quenching phenomenon which can be applied for detection of contaminants in water. The nanostructured profile enhances the surface area of the films exposed to the quencher. The fluorescence quenching of $\mathrm{ZnO}$ NRs was tested by three organic solvents dissolved in distilled water (adding 1\% of organic solvent). The sample exposed to pure distilled water was used as a reference. All three solvents caused quenching of both excitonic and defect luminescence. The strongest quenching was observed for dimethylsulfoxide ( $94 \%$ for the UV band and $85.6 \%$ for the green band). The presence of chloroform decreased emission by $64.9 \%$ (UV band) and $35.5 \%$ (green band), and the presence of methanol by $52 \%$ (UV band) and by $48.7 \%$ (green band).

\section{Conclusions}

In conclusion, films containing $\mathrm{ZnO}$ NRs with a controllable diameter $(60-300 \mathrm{~nm})$ have been grown by the ACG technique. The obtained $\mathrm{ZnO}$ NRs showed efficient excitonic emission indicating high optical quality of the films. Optimal conditions for the growth of size-controllable $\mathrm{ZnO}$ NRs were elucidated. Excellent photoluminescence properties and high surface area of $\mathrm{ZnO} \mathrm{NR}$ films enable their application for detection of organic contaminants in water.

\section{References}

[1] Ü.Özgür,Y.I.Alivov, C.Liu,A.Teke, M.A. Reschikov, S. Doğan, V. Avrutin, S.-J. Cho, and H. Morkoç, A comprehensive review of $\mathrm{ZnO}$ materials and devices, J. Appl. Phys. 98, 041301 (2005).

[2] A.B. Djurišić, A.M.C. Ng, and X.Y. Chen, $\mathrm{ZnO}$ nanostructures for optoelectronics: Material properties and device applications, Progr. Quant. Electr. 34, 191-259 (2010).

[3] L.L. Yang, Q.X. Zhao, and M. Willander, Sizecontrolled growth of well-aligned $\mathrm{ZnO}$ nanorod arrays with two-step chemical bath deposition method, J. Alloys Comp. 469, 623-629 (2009).

[4] N.H. Alvi, K. Ul Hasan, O. Nur, and M. Willander, The origin of the red emission in $\mathrm{n}-\mathrm{ZnO}$ nanotubes/ p-GaN white light emitting diodes, Nanosc. Res. Lett. 6, 130 (2011).

[5] M.Karaliūnas, T. Serevičius, E. Kuokštis, S. Juršènas, S.Y. Ting, J.J. Huang, and C.C. Yang, Optical characterization of MBE-grown $\mathrm{ZnO}$ epilayers, Adv. Mater. Res. 222, 86-89 (2011).

[6] P.V. Kamat, R. Huehn, and R. Nicolaescu, A "Sense and Shoot" approach for photocatalytic degradation of organic contaminants in water, J. Phys. Chem. B 106, 788-794 (2002). 


\title{
ŽEMATEMPERATŪRIU BŪDU UŽAUGINTỤ ZnO NANOSTRYPELIŲ SAVYBĖS BEI TAIKYMAS JUTIKLIAMS
}

\author{
T. Serevičius, S. Juršènas
}

Vilniaus universiteto Taikomujų mokslu institutas, Vilnius, Lietuva

\section{Santrauka}

Cheminio auginimo iš tirpalo metodu buvo gauti $\mathrm{ZnO}$ nanostrypelių sluoksniai su valdomomis morfologinèmis savybèmis, auginimo metu keičiant auginimo trukmę bei reagentų koncentraciją. Užauginti sluoksniai buvo tirti taikant nuskaitančio elektronų mikroskopo bei fotoliuminescencijos metodus. Tyrimai nuskaitančiu elektronų mikroskopu parodè, jog $\mathrm{ZnO}$ nanostrypeliai yra 2-2,5 $\mu \mathrm{m}$ aukščio ir $60-300 \mathrm{~nm}$ skersmens. $\mathrm{ZnO}$ nanostrypeliu fotoliuminescencijos spektre stebimos dvi juostos: laisvujų eksitonų bei žalioji - defektų. Mažo intensyvumo sužadinimo atveju spektre vyraujanti laisvụjų eksitonų liuminescencijos juosta rodo aukštą nano- struktūru optinę kokybe, palyginamą su $\mathrm{ZnO}$ epitaksiniu sluoksniu. Didelio intensyvumo fotosužadinimo atveju pastebèta, kad eksitonų liuminescencijos intensyvumas nanostrypeliuose, storesniuose nei $160 \mathrm{~nm}$, pradeda mažèti, veikiausiai dèl gretimų nanorypelių suaugimo. Dèl didelio paviršiaus ploto $\mathrm{ZnO}$ nanostrypelių sluoksnių liuminescencijos intensyvumas yra jautrus aplinkos poveikiui. Liuminescencijos gesimas ištirtas $\mathfrak{i}$ vandeni ipylus nedaug organinių tirpiklių. Labiausiai $\mathrm{ZnO}$ nanostrypelių liuminescenciją gesino $1 \%$ dimetilsulfoksido tirpalas (apie $90 \%$ ). Toks didelis jautris organiniams teršalams leidžia panaudoti $\mathrm{ZnO}$ nanostruktūras organinių tirpiklių detekcijai. 